ElementerIs: Jurnal Ilmiah Pendidikan Dasar Islam

Volume 1 Nomor 2 November 2019

e-ISSN: 2655-6324

\title{
PENINGKATAN MOTIVASI BELAJAR SISWA MELALUI PENERAPAN METODE HYPNOTEACHING PADA MATA PELAJARAN IPS SISWA KELAS V SD NURUL IJTIHAD PUJUT LOMBOK TENGAH
}

\author{
Buana Sari ${ }^{1}$ Baiq Arnika Saadati², Muhamad Sadli ${ }^{3}$ \\ Program Magister Pendidikan Guru Madrasah Ibtidaiyah \\ Universitas Islam Negeri Sunan Kalijaga Yogyakarta \\ Universitas Islam Negeri Maulana Malik Ibrahim Malang. \\ 1buanasari945@gmail.com²arnikasaadati@gmail.com \\ 3muhamadsadli040414@gmail.com
}

Diterima: 18 Oktober 2019 I Direvisi: 09 Desember 2019 I Disetujui: 09 Desember 2019 (C) 2019 Pendidikan Guru Madrasah Ibtidaiyah Fakultas Agama Islam Universitas Islam Malang

\begin{abstract}
Abstrack
This research aims to improve the learning motivation students through the application of hpnoteaching methods on social studies fifth grade of Nurul Ijtihad Pujut elementary school even semester 2016-2017. The type of this research is classroom action research with Kurt Lewin's model. This research consisted of two cycles, and each cycle is made up of one meeting, data collection techniques were observation, questionnaires, and documentation. The observation used to see the activities of the teacher and the students while the questionnaires used to see student learning motivation. Data analysis was using techniques analysis quantitative descriptive. The object of this study is the fifth grade of elementary school Nurul Ijtihad Pujut. The results showed that the implementation of hpnoteaching method could improve student learning motivation. It can be seen from achieving category values, in the first cycle, the average score of learning motivation is 28 with a percentage of $40 \%$ with quite high category, and $60 \%$ high category. In the second cycle, the average score of learning motivation is 41.6 with a percentage of 30\% high category and $70 \%$ very high category.
\end{abstract}

Keyword: Learning Motivation, Social Studies, Hypnoteaching Methods

\begin{abstract}
Abstrak
Penelitian ini bertujuan untuk meningkatkan motivasi belajar siswa melalui penerapan metode pembelajaran IPS pada kelas V SDN Nurul Ijtihad Pujut pada semester 2016-2017. Jenis penelitian ini adalah penelitian tindakan kelas dengan model Kurt Lewin. Penelitian ini terdiri dari dua siklus, dan setiap siklus terdiri dari satu pertemuan, teknik pengumpulan data diamati, kuesioner, dan dokumentasi. observasi digunakan untuk melihat aktivitas guru dan siswa sedangkan angket
\end{abstract}


digunakan untuk melihat motivasi belajar siswa. Analisis data menggunakan teknik analisis kuantitatif deskriptif. Objek penelitian ini adalah siswa kelas V Sekolah Dasar Nurul Ijtihad Pujut. Hasil penelitian menunjukkan bahwa penerapan metode pengajaran mengajar dapat meningkatkan motivasi belajar siswa. Hal ini dapat dilihat dari pencapaian nilai kategori, pada siklus pertama, skor rata-rata motivasi belajar adalah 28 dengan persentase 40\% dengan kategori cukup tinggi, dan kategori tinggi 60\%. Pada siklus kedua, skor rata-rata motivasi belajar adalah 41,6 dengan persentase kategori tinggi 30\% dan kategori sangat tinggi 70\%.

Kata kunci: Motivasi Belajar, Ilmu Sosial, Metode Hypnoteaching

\section{Pendahuluan}

Setiap aktifitas, termasuk aktivitas belajar digerakkan oleh suatu keinginan, hasrat, atau beberapa m ot if. Motif dapat diartikan sebagai energi penggerak yang berada pada diri individu sebagai stimulus untuk melakukan kegiatan tertentu guna mencapai suatu tujuan. Stimulus tersebut terjadi secara sengaja dan tidak sengaja untuk melakukan tindakan atau kegiatan- (Djamarah, 2002).

Abraham Maslow mendefinisikan motivasi sebagai sesuatu yang bersifat konsisten, kontinu dan tetap (Prawira, 2013). Motivasi merupakan suatu hal kompleks yang menyebabkan terjadinya suatu perubahan energi yang ada pada diri manusia, sehingga akan bergayut dengan persoalan psikologis berupa feeling dan emosi untuk kemudian bertindak melakukan sesuatu (Rohmah, 2012).

Dalam kegiatan pembelajaran, motivasi merupakan totalitas energi yang menggerakkan, menghantarkan, membangkitkan, dan menumbuhkan kegiatan belajar mengajar sehingga tujuan yang dikehendaki dapat tercapai (Sutikno, 2013). Apabila peserta didik memiliki motivasi yang tinggi maka dapat menimbulkan aktivitas pembelajaran dan sebaliknya apabila dalam diri peserta didik tidak terdapat motivasi maka tidak dapat menimbulkan aktivitas pembelajaran.

Guru dapat berupaya dengan maksimal untuk meningkatkan motivasi belajar pada siswa siswa dengan menghadirkan nuansa belajar yang menyenangkan dan tidak monoton. Dengan demikian, guru dituntut untuk menguasai seni pembelajaran yang pariatif, lebih fresh, dan memiliki prospek bagi dunia pendidikan. Karena, Seni mengajar merupakan hal fundamental yang berkaitan dengan metode pembelajaran agar dapat mempengaruhi daya tangkap siswa terhadap materi ajar ( $\mathrm{R}, 2013)$.

Berdasarkan hasil observasi terhadap m ot i v a s i siswa kelas V SD Nurul Ijtihad Pujut Lombok Tengah menunjukkan bahwa siswa memiliki motivasi belajar yang rendah. Hal ini dapat dilihat dari kegiatan pembelajaran. Mereka 
kurang bersemangat, kurang antusias, terlihat lesu, mengantuk, bermain, dan tidak memperhatikan topik pembelajaran yang disampaikan gurunya. Aktivitas guru ketika proses pembelajaran juga berlangsung monoton. Guru masih menerapkan sistem pembelajaran konvensional yaitu sistem pembelajaran yang hanya menggunakan metode ceramah saja sedangkan siswa hanya diarahkan untuk mencatat bacaan. Dengan demikian, kegiatan belajar mengajar hanya berorientasi pada guru (teacered centered).

Agar proses pembelajaran dapat berlangsung aktif dan berpusat kepada siswa (student centered), maka guru harus mereparasi atau memperbaiki kegiatan pembelajaran yang mampu menggugah semangat peserta didik. Salah satu upaya yang dapat dilakukan adalah dengan memberikan rangsangan berupa motivasi yang berasal dari luar diri peserta didik atau motivasi ekstrinsik. (Syaodih, 2010).

Tindakan yang dipilih peneliti untuk memberikan motivasi kepada siswa adalah dengan menerapkan metode hypnoteaching. Metode hypnoteaching dalam penelitian ini adalah melakukan perubahan pembelajaran yang monoton, konvensional dan menjenuhkan bagi siswa menjadi pembelajaran yang asyik dengan suasana nyaman, rileks, fokus, dan menciptakan pembelajaran yang kondusif, sehingga peserta didik merasa senang ketika mengikuti kegiatan belajar mengajar (Mahardika, 2015). Adanya perasaan senang dan nyaman ketika proses pembelajaran tentu akan berdampak pada peningkatan motivasi belajar siswa.

\section{Kajian Teori}

\section{Pengertian Motivasi Belajar}

Thomas M. Risk menjelaskan bahwa motivasi adalah usaha yang dilakukan dengan sengaja oleh pendidik untuk menggugah keinginan pada diri siswa untuk melakukan aktifitas belajar sehingga siswa dapat mencapai tujuan belajar.Kemudian Nasution mengemukakan bahwa motivasi adalah menciptakan kondisi peserta didik sedemikian rupa sehingga mereka memiliki kemauan untuk mengerjakan apa yang dapat dikerjakannya (Rohani, 2004). Sedangkan Motivasi menurut Santrock adalah proses yang memberi semangat, arah, dan kegigihan perilaku. Artinya perilaku yang termotivasi adalah prilaku yang penuh energi, terarah dan bertahan lama (Santrock, 2013)

Berdasarkan pengertian tersebut, dapat disimpulkan bahwa motivasi belajar adalah energi yang timbul dalam diri seseorang yang dapat merubah perilakunya untuk berbuat sehingga dapat mencapai tujuan belajar dengan 
maksimal. Dalam proses pembelajaran, motivasi merupakan komponen utama dan menempati posisi penting. Murid atau siswa yang bermotivasi tinggi akan senang melakukan kegiatan pembelajaran.

\section{Macam-macam Motivasi Belajar}

1. Motivasi Intrinsik

Motivasi intrinsik merupakan motivasi internal yang muncul secara alami tanpa ada tekanan dan paksaan dari orang lain. Motivasi ini biasa disebut "motivasi murni" atau motivasi yang sebenarnya. Misalnya siswa yang memiliki kemauan untuk mendapatkan keterampilan, pengetahuaan, dan sikap tertentu untuk keberhasilannya (Nasution, 2010).

Dalam aktifitas pembelajaran, Seseorang yang memiliki motivasi intrinsik dapat melakukan kegiatan belajar secara kontinu. Selain itu, Seseorang yang memiliki motivasi intrinsik cenderung berkeinginan untuk berhasil dalam belajar. Keinginan tersebut dilatar belakangi oleh cara berfikir yang positif. Mereka selalu beranggapan bahwa semua hal yang dipelajari saat ini akan dibutuhkan untuk masa kini dan masa mendatang. (Djamarah, 2002)

2. Motivasi Ekstrinsik

Motivasi ekstrinsik adalah daya penggerak yang berasal dari luar. Motivasi ekstrinsik sering dipengaruhi oleh insentif eksternal(Syaoidih, 2010). Pemberian motivasi ekstrinsik Dalam dunia pendidikan sangat diperlukan agar peserta didik memiliki kemauan untuk belajar. Karena itu guru yang dikatakan berhasil dalam mengajar adalah guru yang mampu menggugah semangat belajar peserta siswa-siswanya.

\section{Indikator Motivasi Belajar}

Pada hakikatnya motivasi dalam proses belajar berfungsi sebagai penggerak untuk melakukan kegiatan belajar sehingga dapat mencapai tujuan belajar. Motivasi dapat dikonseptualisasikan dari intensif yang baik terutama berasal dari internal dan eksternal. Indikator motivasi belajar ditandai dengan (Nasution, 2010).

1) Munculnya minat dan ambisi untuk sukses

2) Terdapat kemauan dan keinginan untuk belajar

3) Terdapat impian dan cita-cita dalam belajar

4) Timbulnya rasa senang dan puas dalam mengerjakan tugas

5) Menemukan aktivitas menyenangkan dalam kegiatan belajar

6) Adanya reward dan punishment dalam pembelajaran

7) Adanya lingkungan belajar yang mendukung sehingga memungkinkan peserta didik bisa belajar dengan tenang. 


\section{Pengertian Metode Hypnoteaching}

Hypnoteaching berasal dari kata hipno dan teaching. Hipno berarti mensugesti dan teaching berarti mengajar. Menurut Novian Triwidia Hypnoteaching merupakan kegiatan proses belajar mengajar yang mengikutsertakan pikiran sadar dan bawah sadar siswa (Yustiana, 2012). Sementara itu, Hypnoteaching menurut Hajar adalah sebuah keterampilan berkomunikasi yang dilakukan dengan menyampaikan sebuah sugesti agar peserta didik menjadi lebih pintar. Sedangkan makna Hypnoteaching menurut Muhamad Noer adalah guru menerapkan penggunaan bahasa yang halus sebagai alat komunikasi yang sesuai dengan keinginan peserta didik. Artinya bahwa guru tidak membuat siswa tertidur seperti hipnotis pada umumnya(HR, 2015).

Dari berbagai pendapat mengenai metode Hypnoteaching yang telah dikemukakan tersebut dapat disimpulkan bahwa Hypnoteaching adalah metode pembelajaran yang digunakan agar siswa fokus, rilax, nyaman, termotivasi, dan terkendali ketika proses pembelajaran berlangsung.

\section{Ciri-ciri Kondisi Hipnotis dalam Proses Pembelajaran}

Kondisi hipnotis Ketika proses pembelajaran berlangsung dengan menggunakan metode Hypnoteaching ditandai dengan beberapa hal yaitu diantaranya (a) Perhatian yang terfokus, (b) Relaksasi fisik, (c) Peningkatan sebagian atau seluruh panca indra, (d) Pengendalian reflex dan aktivitas fisik, (e) Respons peserta didik sebagai pengaruh pascahipnotis (Mahardika, 2015).

\section{Langkah-Langkah Hypnoteaching}

Dalam mengimplementasikan metode Hypnoteaching pada pembelajaran ada beberapa step-step dasar yang wajib diperhatikan agar guru mampu menerapkan Metode ini, yaitu (a) niat dan motivasi dalam diri, (b) relaksasi fisik, (c) pacing, (d) leading, (e) menggunakan kata-kata positif, (f) memberikan pujian, (g) modeling (Budiarso, Pengembangan Bahan Ajar Berbasis Metode Hypnoteaching Unruk Meningkatkan Motivasi belajar Siswa dalam Pembelajaran IPA, 2016).

\section{Metode Penelitian}

Penelitian ini dilaksanakan di SD Nurul Ijtihad yang berada di wilayah Montong Balas Senang Desa Pengembur Kecamatan Pujut Kabupaten Lombok Tengah Provinsi NTB. Penelitian ini dilaksanakan pada siswa kelas IV SD Nurul Ijtihad Montong Balas. Peneliti melakukan penelitian di SD tersebut karena peneliti mengidentifikasi permasalahan yang terjadi terhadap motivasi belajar 
siswa. Hal ini berdasarkan hasil temuan peneliti pada saat melaksanakan studi pendahuluan. Penelitian ini dilaksanakan pada bulan mei dari tanggal 2 s/d 31 Mei.

Metode yang digunakan pada penelitian ini adalah penelitian tindakan kelas. Secara historis penelitian tindakan pertama kali dikemukakan oleh Kurt Lewin pada tahun 1946. Penelitian tindakan dalam dunia pendidikan dapat diterapkan pada sebuah kelas sehingga disebut sebagai penelitian tindakan kelas. R O'Brien mendefinisikan penelitian tindakan sebagai learning by doing yang didalamnya seseorang mengidentifikasi suatu masalah, melakukansesuatu untuk menyelesaikannya, melihat seberapa hasil upaya tersebut, dan jika tidak puas akan mencoba lagi. Model tindakan yang digunakan pada penelitian ini adalah model Kurt Lewin (Kesuma, 2013). Dalam penelitian ini peneliti menggunakan pendektan kuantitatif deskriptif. Data kuantitatif didapatkan dari hasil penyebaran angket motivasi siswa dan dideskripsikan setelah peneliti melakukan pengolahan data. Sedangkan rencana tindakan terdiri dari empat tahapan yaitu, tahap perencanaan, pelaksanaan, pengamatan, dan refleksi melalui siklus pertama dan kedua (Suyadi, 2012).

Instrumen penelitian yang digunakan pada penelitian ini adalah lembar pengamatan, angket, dan dokumentasi. Pengamatan merupakan teknik untuk mengumpulkan data secra langsung dengan alat observasi (Senjaya, 2011). Pengamatan yang dilaksanakn pada penelitian ini adalah pengamatan langsung untuk memantau kegiatan siswa dan kegiatan guru ketika proses belajar mengajar berlangsung. Selanjutnya angket digunakan untuk mendapatkan informasi dari responden (Arikunto, Prosedur Penelitian Suatu Pendekatan Praktik, 2010). Adapun angket yang digunakan pada penelitian ini adalah angket tertutup. Angket tertutup yaitu angket yang jawabannya telah disiapkan terlebih dahulu dari pertanyaan yang diberikan kepada responden. Sedangkan dokumentasi dipilih untuk mendapatkan data berupa laporan tertulis, peraturan-peraturan, laporan agenda, foto kegiatan, rekaman agenda, dan data yang sesuai dengan konteks penelitian (Sugiyono, 2014).

\section{Hasil Penelitian dan Pembahasan}

Peningkatan motivasi belajar siswa yang rendah di SD Nurul Ijtihad Montong Balas dilakukan dengan memperbaiki kegiatan pembelajaran melalui penerapan metode yang kreatif, aktif, menyenangkan, dan tidak monoton. Salah satu metode yang dapat digunakan adalah dengan mengimplementasikan metode Hypnoteaching. 


\section{Hasil Tindakan Siklus Pertama}

Pada tindakan siklus pertama hal yang paling utama dipersiapkan adalah perencanaan seperti menyiapkan rencana pelaksanaan pembelajaran (RPP), menyiapkan fasilitas yang dibutuhkan di dalam kelas, seperti: bahan ajar, alat peraga, perangkat lain yan dibutuhkan dan yang diperlukan, serta menyiapkan angket untuk mengetahui peningkatan motivasi siswa.

Hasil penelitian setelah diberikan tindakan pada siklus pertama menunjukkan adanya peningkatan motivasi belajar siswa bila dibandingkan dengan hasil pada pra tindakan. Rata-rata hasil motivasi peserta didik pada siklus pertama setelah diadakan tes motivasi mencapai skor rata-rata sebesar 28 dengan dengan presentase sebesar 40 \% (kategori cukup tinggi) dan 60\% (kategori tinggi). Sedangkan hasil aktivitas siswa mencapai 10,06 dengan kategori cukup aktif dan hasil aktivitas guru mencapai 11,75 termasuk kategori cukup aktif.

Penerapan metode hypnoteaching pada siklus pertama belum dilaksanakan secara maksimal diantaranya: (1) Pada kegiatan Self Motivation, Guru tidak mengecek kehadiran siswa dan tidak menunjukkan sikap yang ramah. Padahal, tindakan tersebut bertujuan agar siswa dan guru menjadi lebih akrab dan rileks sebelum melaksanakan kegiatan pembelajaran. (2) Di tahap apersepsi, guru tidak menyampaikan tujuan pembelajaran. sehingga peserta didik kurang termotivasi untuk mengikuti kegiatan pembelajaran. (3) Pada kegiatan inti, guru tidak memberikan kesempatan kepada peserta didik untuk bertanya tentang materi yang belum dimengerti, sehingga siswa terlihat pasif ketika kegiatan belajar mengajar berlangsung. Oleh karena itu, perlu dilakukan tindakan lagi untuk melakukan perbaikan terhadap hambatan yang muncul pada siklus pertama.

\section{Hasil Tindakan Siklus Kedua}

Pelaksanaan pembelajaran pada siklus kedua dengan menggunakan metode Hypnoteaching berjalan lebih kondusif. Aktivitas siswa dan guru juga berada pada kategori sangat baik. Pada siklus kedua jumlah skor rata-rata motivasi siswa mencapai 41,6 dari hasil angket yang disebar oleh guru dengan kategori tinggi sebesar 30\% dan kategori sangat tinggi sebesar $70 \%$. Sedangkan aktivitas siswa meningkat menjadi 14,32 dengan kategori aktif dan aktivitas guru meningkat menjadi 14,6 kategori aktif.

Berdasarkan hasil yang telah diperoleh pada setiap siklus maka dapat dikatakan bahwa penelitian ini telah berhasil mencapai indikator yang telah ditentukan. Dari hasil observasi terhadap peningkatan belajar siswa dengan menggunakan metode Hpnoteaching, tampak bahwa siswa telah menunjukkan 
sikap yang memiliki motivasi belajar. Siswa memiliki kemauan, keinginan, antusias, dan aktif, ketika mengikuti kegiatan belajar mengajar. Siswa juga merasa senang untuk mempelajari IPS. Dengan demikian, secara keseluruhan guru telah mengimplementasikan semua unsur-unsur pembelajaran dengan menggunakan metode hypnoteaching, sehingga dapat meningkatkan motivasi belajar siswa.

\section{Simpulan}

Penerapan metode hypnoteaching dapat meningkatkan motivasi belajar siswa. Peningkatan motivasi belajar siswa dilihat dari nilai skor rata-rata motivasi belajar siswa. Pada siklus pertama skor siswa sebesar 28 dengan presentase $40 \%$ kategori cukup tinggi, 60\% kategori tinggi. Pada siklus kedua skor rata-rata motivasi siswa sebesar 41,6 dengan presentase 30\% kategori tinggi 70\% kategori sangat tinggi. Dengan demikian, peningkatan rata-rata motivasi belajar siswa meningkat menjadi 13,6 \% pada siklus ke kedua. Dengan demikian, melalui implementasi metode hypnoteaching, motivasi belajar siswa dapat meningkat karena guru menciptakan suasana pembelajaran yang nyaman dan menyenangkan.

\section{Daftar Rujukan}

Arikunto, S. (2010). Prosedur Penelitian Suatu Pendekatan Praktik. Jakarta: Rineka Cipta.

Arikunto, S. (2016). Penelitian Tindakan Kelas. Jakarta: Bumi Aksara.

Budiarso, A. S. (2016). Pengembangan Bahan Ajar Berbasis Metode Hypnoteaching Unruk Meningkatkan Motivasi belajar Siswa dalam Pembelajaran IPA. Pena Sains, 135.

Budiarso, A. S. (2016). Pengembangan Bahan Ajar Berbasis Metode Hypnoteaching Untuk Memotivasi Siswa Dalam Pembelajaran IPA . Pena Sains, 135.

Djamarah, S. B. (2002). Psikologi Belajar. Jakarta: PT Rineka Cipta .

HR, M. (2015). Menciptakan Pembelajaran Efektif Melalui Hypnoteaching. e-Buletin , 5.

Kesuma, A. T. (2013). Menyusun PTK Itu Gampang. Jakarta: Erlangga.

Mahardika, D. (2015). Menerapkan Hypnoteaching. Yogyakarta: Diva Press.

Mulyatiningsih, E. (2013). Metode Penelitian Terapan Bidang Pendidikan . Bandung: Alfabeta.

Nasution. (2010). Didaktik Asas-asas Mengajar . Jakarta: Bumi Aksara. 
Buana Sari, Baiq Arnika Saadati, Muhamad Sadli

Prawira, P. A. (2013). Psikologi Pendidikan dalam Perspektif Baru . Jogjakarta: ArRuzz Media.

R, H. T. (2013). Seni Mengajar Ala Pelatih Top Sepak Bola Dunia. Yogyakarta: Diva Press.

Rohani, A. (2004). Pengelolaan Pengajaran. Jakarta: PT Rineka Cipta.

Rohmah, N. (2012). Psikologi Pendidikan. Yogyakarta: Teras.

Santrock, J. W. (2013). Psikologi Pendidikan. Jakarta: Kencana.

Senjaya, W. (2011). Penelitian Tindakan Kelas. Jakarta: Kencana.

Sugiyono. (2014). Metode Penelitian Kuantitatif dan Kualitatif. Bandung: Alfabeta.

Sutikno, S. (2013). Belajar dan Pembelajaran . Lombok: Holistica.

Suyadi. (2012). Panduan Penelitian Tindakan Kelas . Yogyakarta: Diva Press.

Syaodih, I. d. (2010). Perencanaan Pengajaran. Jakarta: Rineka Cipta.

Syaoidih, I. d. (2010). Perencanaan Pengajaran. Jakarta: Rineka Cipta.

Yustiana. (2012). Hypnoteaching. Yogyakarta: Ar-Ruzz Media. 